\section{ANTHROPOLOGY, SOCIETY AND DEVELOPMENT IN NEPAL: A NATIVE PERSPECTIVE}

\author{
Padam Lal Devkota*
}

\section{Introduction}

Anthropology is a neglected discipline in Nepal. Most anthropologists in the country confine themselves to teaching at the universities rather than reaching the people en masse at the grass-roots level of the country. The relevance of the discipline to nation-building is not fully recognized by the state. Despite these obstacles, students of Nepalese anthropology have recently engaged in digging new foot-steps to the discipline in the country. This paper is one of the efforts to such foot stepping. The purpose of the paper is to provide readers a precise vision on anthropology, society and development of Nepal. The paper is divided into three sections. The first section sketches the history of the development of the discipline and sets out a new focus and framework for the discipline and sets out a new focus and framework for the study of Nepalese society and culture. The second section examines the concept of 'state-centric' development in relation to the existing theories and practices of anthropology in the country. Finally, a brief conclusion is drawn with a set of proposals for future homework.

\section{Descriptive Ethnography and 'Soul Searching' Innovation}

Development of anthropology as a discipline of study, teaching and research in Nepal has a short history. The credit goes to early writings of missionaries and travelers, for example

\footnotetext{
* Dr. Padam Lal Devkota is the Senior Lecturer in Antliropology at the Central Department of Sociology and Anthropology, Tribhuvan University, Kirtipur, Kathmandu.
}

: Kirkpatrick (1811), Hamilton (1819), Hodson (1874) and Oldfield (1880) who inspired for the development of anthropology in the country. The later period is marked with the massive production of descriptive ethnographic accounts most of which concentrate attention on the elaboration of various aspects of Nepalese society, culture and social institutions. Some examples of these types of studies are : Haimendorf (1964, 1966,1975,1986), Hitchcock (1966, 1976), Gabbrieau (1972), Pignede (1970) and Nepali (1965).

The focus during this period was upon religion, fatalism, shamanism, rituals and many other wonderful aspects of human life. These were considered to be the most relevant subject matters of anthropology in the eyes of those western scholars. The first seminar on "spirit possession in Nepal Himalaya" held in mid-seventies itself justified that the dominant anthropological trademark of the period was 'Soul-searching' through spirit possession (Hitchcok and Rex1976).

\section{Euro-centric Traditions and Cultural Romanticism}

The period prior to mid-seventies is marked with the production of vast descriptive ethnographic accounts on Nepalese society and culture. The dominant anthropological approach was cultural romanticism brought into the country by the scholars of the western countries. This approach was 'Eurocentric' and pays no attention to the high cost people pay as the providers of their cultural clues for nothing but to meet the practitioners' needs of personal romanticism and professional development. It is unfortunate that this tradition of cultural romanticism is still firmly footed in our intellectual structure, order and disciplinary practices. Thus, Nepalese anthropology has been still highly dominated and overshadowed by the conventional approaches, methods and practices most of which have been borrowed from the western countries. The country of shan-gri-la is a most favourite place for romantic field work to those western scholars, whose social life is tired with material abundance (Galtung, 1982) in their own countries.

The super-imposition of powerful theories of 'soulsearching' and methods of 'cultural romanticism' from western 
scholars (See Fisher, 1987, Devkota, 1983) and renewal of the noble concept of 'fatalism and development' (Bista, 1991) inside the country, force anthropology of Nepal to stay at the crossroads of intellectual colonialism and cultural romanticism.

\section{Social Change Studies and Elaboration of Western Theories}

Anthropological studies which focus on social change as the unit of study have been undertaken by Caplan $(1970,1975)$, Caplan (1972), Macfarlane (1976), Iijima (1977), McDaugal (1968) and Poffenberger (1980). These scholars concentrate their efforts upon testing and elaborating the theories and concepts of social change mostly originated in the west on the Nepalese socio-cultural setting (Mishra, 984). The efforts have been made to identify the forces of change and their consequences on the present condition of social life. The long historical processes involved behind the origin of such forces of social dynamics, acceptance, resistance in the fabric and framework of glorious traditions, and, deep-rooted socio-psychological sentiments and pragmatic interpretations of cultural practices have been swept under the carpet of superficial description of acts and facts of the phenomena under the study. In these studies, the underlying patterns and processes of change and transformation have remained discrete, descriptive, highly localized and historically less informed. Some native scholars (Regmi 1971; Bista, 1991; Nepali, 1965 and Mishra 1984) have made their excellent contributions to these areas than those of the western scholars.

\section{Applied Anthropology and Documentation of Good Practices of People}

Application of anthropological knowledge for nationbuilding was a forgotten concern to most of the scholars prior to mid-seventies. New trends gradually began to emerge when a few scholars(Wake, 1980; Justice 1986 and Messerschmidt 1995) diverted the discipline to influence state policies and practices. But these studies also lacked a full understanding of history, culture and issues hidden inside the core of the social structure. The major efforts in these studies were put to harness the resistance aspect of the culture under the specific context of modernisation, technology transfer and other mal-consequences as resulted through the process of state-centric planned interventions. Most of these studies regard culture as the major constraint in development and anthropological 'first-aid' is suggested to check up the fragile failure of 'show-case' scheme of 'state-centric' development. These studies hardly pin-point the ills of existing development system and ignore the fact that without a full understanding of these ills, anthropological 'firstaid' could provide only a short term relief. However, a detail documentation of good practices of the society with special reference to local knowledge system is the major strength behind these studies.

The review provides a clear vision that most anthropological writings on Nepal are heavily dominated by western scholars and scholarships. The major trends still revolve around the grand idea of 'fatalism and development' which ultimately leads us to the world of cultural romanticism, the existing practices and intellectual romanticism. The existing practices and intellectual trend within the discipline forces us to infer that anthropology of Nepal has been almost the anthropology of the foreigners. True, there have been voices of protest. As Mikesell noted that:

For scholars in Nepal, it is essential not to accept sociology and anthropology according to the dominant definition as handed from western countries, especially since most powerful voice most easily transfer themselves to Nepal, however, inappropriate their grafts (Mikesell 1992:6)

New visions among the native anthropologists have been gradually emerging and attention is being paid to explore the fundamental bases of Nepali society and culture. Voices have been raised in the line to Nepalize the discipline (Bista, 1987, Sharma, 1989) and display the disciplinary relevance to the service of the people and the state (Mishra 1984, Devkota 1992). But these voices are either ignored or manipulated by giving new meanings and definitions to the context under debate by the powerful masters of the discipline (Fisher, 1987). Attempts to institutionalize the discipline within the country is in gradual 
progress, but the road is still not free from risk and challenges. In his overall assessment of the sorry state of anthropology in Nepal, Mishra says:

We are unable to explore on the essential coherence of our social life. Unable as we are unable to deal with the whole, we make a virtue out of dealing with parts. Even worse, many of us mistake the parts for the whole. In a process what we loose is a certain meaningfulness, a certain coherence. What we gain is a misrepresentation, a distortion (Mishra $1985: 5$ )

\section{Incomplete Homework under Divided Mentality}

The vast stock of micro-level accounts which resulted through conventional descriptive ethnography have been left over there without much use by the state for planning and policy purpose. The native anthropologists hold conflicting views on the use of this stock of sitting knowledge. Some suggest (Regmi 1992, Dahal 1983) the need for a detailed analysis of these studies to come out with a macro-level theoretical framework which could be used as a model for the analysis of the Nepalese society and culture. Some others (Bista, 1983 Sharma, 1989) argue that the time is ripe to renew the discipline in the line of the development of a separate school of thought for the study of Nepali society and culture. There are some others also (Mishra, 1984, Devkota, 1982) who advocate that the discipline should move along with the wheel of time to address the burning issues of Nepalese social structure. Whatever issues native anthropologists raise or advocate, too little has been achieved on the prospect of Nepalization of the discipline. The homework is left pending with a hope to be pursued once again by the foreigners

\section{Society and Development in Nepal}

Nepal is a Himalayan Hindu Kingdom of complex and rich syncretic religious culture developed in the course of her long and free history. The social universe of Nepali society is parapharsed as ' Car-Varna' and 'Chhattis-jat' (lit. Four colours and thirty-six castes). Religious harmony alongwith social integrity has been always observed among various sects of ethnic groups in the country.
The rural society is characterized with rapid population growth, low level of living and health conditions, widespread worsening poverty and increasing threat from environmental deterioration. The high population growth with her low GDP have been matched with the dual objective of growth and equity. The various facets of poverty which flourish despite the rich cultural heritage is a major challenge before the nation.

The forces of change and practices of development do not match with each other in the country. The policy inconsistencies observed under frequent changes in development strategies (Banskota, 1989; Devkota, 1992) make the achievements more fragile and frustrative. The national economy is running through foreign-aid dominated gift economy. In connection with the impact of foreign aid in the country professor Fisher argues:

.... The open secret is that most foreign aid benefits primarily Nepalese elites, and one can define" development" not without reason, as the process by which the wealth of poor people in rich countries is transferred to the rich people of the poor countries (Fisher, 1987: 31).

As a result, the market economy has penetrated into nomarket economy, participation has been sustained through political paternalism, self-sufficiency is measured under narrow indicators of economic abundance, self-reliance is identified under state-sponsorship, and thus, local autonomy has been framed under new and better imported institutions. Moreover, decentralization and self-govemance are justified through centralized planning and decision making and sustainability is evaluated in terms of patchy and fragile achievements.

\section{Anthropology and Development in Nepal}

The broader agenda of national development as defined under state-centric 'fixed-it' model and current theory and practices in anthropology confront with each other. The ' Statecentric' development model based on the noble idea of central control over planning and grand design of 'trickle-down' effect at the societal level do not meet the promised goals to uplift the quality of life of the country men. The scheme is characterized 
with its several unique features, such as: top-down, uniformal, result-oriented, target bounded, delivery of tangible goods and services from centre to peripheries, static structure and framework and replacement of old with new and better ones. Often the planners interact with structure, with the framework rather than with the beneficiaries. Such a practice of development hardly cover the felt needs of people at the grassroots level. The overall consequences of this type of ' statecentric' development practices can be observed at the various levels of state domination over regional affairs and regional domination of societal affairs (Mishra 1984). The situation could have been improved if it would have been otherwise. The existing practices of ' State-centric' ' top-down' development is leading society from a pillar of self-sufficiency to the post of dependency and domination.

\section{Anthropological Visions and Development Practices in Nepal}

Development is a relative term. Different people are looking it from their own perspective. Humanistic economists draw their attention more toward the development of small scale technology suited to local context and condition (Schumacher 1975) and development of human beings than those of the things (Fromm 1979) based on the philosophy of good work which combines both spiritual and material side of production activities (Schumacher 1979). Kothari (1988) draws our attention more toward the human survival side and recommends the need for global peace and harmony to make possible existence of manking as a whole on this planet. John Galtung (1982) argues that development should be viewed from the humanistic psychology and holistic ecology to the 'Gandhian practice to liberate it from the straight jacket of economics'. Indian political economist Vrajendra Raj Mehta (1978) refers development in the multi-dimensional context of man and society bound under a integrated pluralistic system of 'wholes' within wholes.

Anthropology of development provides a vision that development should start on the most important people on the ground (Fisher, 1987). The knowledge and experiences obtained from the field of anthropology tell one that efforts to be directed to match interventions tell one that efforts to be directed to match interventions with the local culture and value system (Foster, 1962, Spicer, 1952), people based institutions (Taylor, 1965), indigenous knowledge system (Brokenoa, 1953) and basic innovation (Barnett, 1953) resulting into desirable cultural change and societal transformation.

It is evident from the above discussion that development is more a process rather than matter of a state. The process is slow, gradual, bottom-up, building from below, innovative, time consuming, people-centered, realistic, democratic, participatory, liberal, progmatic, small scale, invisible, praxis- oriented, reflexive, humanistic, holistic and long lasting.

But the noble desire of 'State-centric' development in Nepal is highly motivated to achieve immediate results from development intervention to please the donors rather than to meet the real needs of own country people. Thus, anthropological visions to direct 'development from below' naturally becomes a unrealistic phenomena to the planners and policy makers. Under some conditions, anthropologists are blamed as persons who intend to violate fundamental principles of national integrity for their practices on the local communities and culture. The administrators sometimes perceive them as the' water-loo' creators and the " trouble-makers" of all odds, Few bureaucrats put label as the 'patron-king' of culture and some others see them simply as 'cultural-romanticists'.

In Nepal, anthropologists are not desirable persons to planners and policy makers. Anthropologists' involvement is mostly avoided in many important stages of national planning and policy making events. This notion of avoidance compels anthropologists to become more articulated and even critical to those 'state-centric' development planning processes, policies and practices. Thus, the gap between planners, policy makers and anthropologists is further widened in the country.

The only choice left to the anthropologists was either to confine to teaching at the university or reaching the people through the blooming foreign aid NGOs and INGOs all over the country. Their involvement in these NGOs (Non-Governmental Organisations) and INGOs (International Non-Governmental Organisations) is mostly on short- term basis based on a contract of 
'hired and fired' conditions. The role they perform in these agencies include: facilitators, match-makers, watchdogs, cultural brokers, change agents, interventionists, mobilizers, interpreters and reportwriters. Involving anthropologists in development programmes indicates not a belief in success but deeply rooted fear of failure.

Most of these NGOs and INGOs operate under state defined system of development framework popularly known as 'going through the system' philosophy followed by the powerful donor agencies. The intention behind such a philosophy is clear: to strengthen the hands of 'state-centric' development mechanism and machinery that functions high above and beyond the knowledge and reach the ordinary people. Their interaction with high structure and abstract framework compel these NGOs and INGOs to forget the important people on the ground. The penetration of foreign aided NGOs and INGOs all over the country has increased public expectations and dependency without doing much to those who have suffered generations of hunger, poverty, domination and deprivation.

\section{Conclusion and Proposal}

Whatever ideal goals Nepalese anthropologists may set to go ahead and actual task at hand they may engage, but the time has now come for them to assess what is being achieved and what has been left behind for the homework, in the course of the history of development of the discipline in the country. The anthropology of Nepal requires a coherent body of theory, concepts and methods for searching the pragmatic answers to the issues of national importance and societal answers to the issues of national importance and societal significance. There is an equal need to tilt the discipline more to the service of the weaker section of society and to address the core issues of social structure manifested under the present context of its cultural dynamics. It is necessary to combine theory with practice in order to comprehend a coherent visibility or multidimensional context of human conditions and make disciplinary knowledge accessible to policy formulating bodies and institutions.

The foremost need is to Nepalize the discipline by breaking the barrier of producer-consumer, provider-receiver, patron-client, and leader-follower relationships between native and western anthropologists. Continuity of cultural heritage, nation building and unity of diversity are some of the areas to be emphasized by the future studies. The widespread and worsening poverty among people is a challenging social reality. The broad social, political, ideological, economic and humanistic context of poverty and its visible consequences should get priority over the disciplinary unit of analysis. Moreover, the conservation of Himalayan environment and preservation of our common cultural heritage are the left over homework before Nepalese and Indian anthropologists.

\section{REFERENCES}

Bista, Dor Bahadur

1983 "The Process of Nepalization", in Anthropoiogical and Linguistic Studies of Gandaki Area in Nepal. Tokyo : Tokyo University Press.

Bista, Dor Bahadur

"Nepal School of Sociology and Anthropological" in James Fisher (ed.) Occasional Papers in Sociology and Anthropology, vol. 1: 6-19.

Bista, Dor Bahadur

1989 "Structure of Nepali Society" in Kamal P. Malla (ed.) Nepal : Perspective on Continuity and Change, Katmandu : Center for Nepal and Asian Studies.

Bista, Dor Bahadur

$1991 \quad$ Fatalism and Development, Calcutta : Orient and Longman.

Banskota, Mahesh

1989 "Nepalese Economy and the Five Year Plans" In Kamal P. Malla (ed.) Nepal : Perspective on Continuity and Change. Kathmandu Research Center for Nepal and Asian Studies.

Caplan, A.P

Priests and Cobblers : A Study of Social Change in a Himalayan Village in Western Nepal, London, Inter Text Books.

Caplan, Lionel

1970

Land and Social Change in East Nepal, London: Routledge and Kegan Paul. 
Caplan, Lionel 1975

Administration and Politics in a Nepalese Town. London: Oxford University Press.

Dahal, Dilli Ram 1983

"Anthropology in Nepal". In Mohan P. (ed.) Social Science in Nepal, pp. 37-49. Kathmandu: Institute of Humanities and Social Sciences, Tribhuvan University.

Dahal, Dilli Ram 1992

Anthropology in Nepal Himalaya: A Critical Appraisal. Paper Presented at the National Congress of Sociology/Anthropology in Nepal. Kathmandu: Sociology/Anthropological Society in Nepal.

Devkota, Padam Lal 1983

"Critique on Development of Infrastructure and Program in Anthropology in Nepal" PP. 50-52. In Mohan P. (ed.) Social Science in Nepal.

Kathmandu: Institute of Humanities and Social Sciences, Tribhuvan University.

Devkota, Padam Lal 1992

Reflection on Participatory Rural Development in Nepal. Calgary: International Centre, University of Calgary.

Devkota, Padam Lal

"Anthropological Perspectives on Grassroots Development in Nepal". Occasional Papers in Sociology and Anthropology $4: 34-50$.

Fisher, James F. (ed.)

1978 "Himalayan Anthropology": The Indo-Tibetan Interface. The Hague: Mouton.

Fisher, James F. (ed.)

1985

Trans Himalayan Traders: Economy Society and Culture in North-West Nepal. Berkeley: University of California Press.
Fisher, James F. (ed.)

1987

"Romanticism and Development in Nepalese Anthropology". Occasional Paper in Sociology and Anthropology. 1:30-42 Kathmandu: Central Department of Sociology and Anthropology, Tribhuvan University.

Foster, Gorge M.

Traditional Societies and Impact of Technological Change. New York: Harper and Row.

Fromm, Eric

1979

To have or to be: A Blue Print of Mankind. London: Abacus.

Gabrrieau

1972

"Muslims in the Himalayan Kingdom of Nepal". Contributions to Indian Sociology,. No.6.

Galtung, John et al.

1982

"Development Centered on Human Being: Some West Europian Perspective" pp. 82-112. In Different Theories and Practices a of Development. Paris :UNESCO.

Gauchan, Yassokanti

1986 Socio-Cultural Change in Thakali Society: An Ethno-Sociological Study of Thakalis of Kathmandu. Kathmandu: Tribhuvan University, Home Science Department.

Haimendorf, $\mathrm{F}$

1964

The Sherpas of Nepal. Berkely: University of California Press.

Haimendorf, F. (ed.)

1966

Caste and Kin in Nepal, India and Cylon. London: Asia Publishing House.

Haimendorf, F

1975

Himalayan Traders. London: Jhon Murray.

Haimendorf, $\mathrm{F}$

1986

The Sherpas Transformed: Social Change in a Buddhist Society. New Delhi: Sterling Pvt. Ltd. 
Hamilton, F. B. 1819

An Account of Kindom of Nepal and of the Territories Annexed to this Domain by the House of Gurkha. Edinburgh: Archibald Constable and Company.

Hitch Cock, John T.

1966 Magars of Banyan Hill. New York: Holt and Rinehart.

Hitch Cock, John T. and Rex C.Jones (ed.)

1976 Spirit Possession in Nepal Himalaya. New Delhi:

Vikas Publishing Company.

Hodson, B. H.

1817

Essays on the Language, Literature and Religion of Nepal and Tibet. London: Trubner and Company.

Iijima, S.

1977

Ecology, Economy and Culture Change among Thakalis in the Himalayas of Central Nepal. In S. Iijima (ed.) Changing Aspects of Modern Nepal. Monumenta Sirindica, No. 1, ILCCA, Tokyo.

Justice, Judith

1986

Policies, Plans and People. Berkeley: University of California Press.

Kirk Patric, C. W.

1811 An Account of the Kingdom of Nepal. London: William Miller.

Macfarlane, A

1976

Resources and Population: A Study of Gurungs of Nepal. Cambridge: Cambridge University Press.

McDaugal, Charles

$1968 \quad$ Village and Household Economy in Far Western Nepal. Kathmandu: Tribhuvan University.

Messerschmidt, Donald, A.

1976 The Gurungs of Nepal: Conflict and Change in a Village Society, New Delhi: Oxford and IBH Publishing House.
Haimendorf, F.

1995

Development Studies. Kathmandu: EMR Publishing House.

Mikesell, Stephen

1992

"Unlocking Submerged Voices: Afro-American Scholarship and Social Science in Nepal." Paper presented in the National Congress of Sociology/Anthropology in Nepal. Kathmandu: Sociological/Anthropological Society of Nepal.

Mehta, Vrajendra

1978 Beyond Marxism: Toward and Alternative Perspective. New Delhi: Manohar Publisher.

Mishra, Chaitanya

1984 "Social Research in Nepal". Contribution to Nepalese Studies 11(2): 1-10

Mishra, Chaitanya

1987

"Development and Under-Development". In Occasional Paper in Sociology and Anthropology.

Vol. 1 PP. 109-137. Kathmandu: Central Department of Sociology/Anthropology, Tribhuvan University.

Nepali, Gopal Singh

1965 The Newars, Bombay: Aisa Publishing House.

Oldfield, N.A.

1880

Sketches from Nepal. London: Allen and Company.

Ottner, Sherry B.

1976

Sherpas Through Their Rituals. Cambridge: Cambridge University Press.

Ottner, Sherry B.

1992

High Religion: Culture and Political History of Sherpa Buddhism. Delhi: Motilal Banarasi Dass Publishers.

Pignede, B.

1966

Les Gurungs: One Population Himalayan du Nepal. Paris: Mouton. 
Poffenberger, Mark

1980 Patterns of Change in Nepal Himalaya. Delhi: Macmillan.

Regmi, Mahesh Chandra

$1971 \quad$ Study of Nepalese Economic History. New Delhi: Manjusri Publishing House.

Regmi, Mahesh Chandra

1976 Land Ownership in Nepal. Berkeley: University of California Press.

Regmi, R. R.

1992

State of Anthropology in Nepal. Paper Presented at the National Congress of Sociology/Anthropology in Nepal. Kathmandu: Anthropological/Sociological Society of Nepal.

Schumacker

1975

Small is Beautiful: A Study of Economics as if People Mattered. London: Sphere Books.

Schumacker

1979

Goodwork. London: Janathan Cape.

Sharma, Prayag Raj

1089

"Nepali Culture and Society: Reflections on Some Historical Currents" In Kamal P. Malla (ed.) Nepal: Perspective on Continuity and Change. Kathmandu: Research Centre for Nepal and Asian Studies, Tribhuvan University.

Spicer, Edward H

1952

Human Problems in Technological Change: A Case Book. New York: Russel Sage Foundation.

Wake, C. J.

1980
Vikas: Evolution in Nepal. Kathmandu: Centre for Nepal and Asian Studies, Tribhuvan University.

\section{POPULATION DYNAMICS AND ENVIRONMENTAL DEGRADATION IN NEPAL: AN OVERVIEW}

\section{Prelude}

By Laya Prasad Uprety*

This paper, in general, makes an endeavour to demonstrate how the population growth in Nepal has been conducive to the environmental degradation. More specifically, this paper is intent on dealing with four objectives, viz., (i) to assess the trends and causes of the population growth; (ii) to assess the increasing demands of growing population on the environment; (iii) to assess the environmental degradation resultant from the population pressure, and (iv) to assess the impact of environmental degradation on the agrarian economy of Nepal.

\section{Trends and Causes of Population Growth: A Glimpse of Population Dynamics}

In Nepal, population has been unprecedentedly growing. Nepal's population which was only 5.6 million in 1911 increased to 18.4 million in 1991. According to the national census of 1991, the population has now been increasing at 2.1 percent per year. Presumably, this rate of growth continues to rise even in the future if the government does not formulate and implement effectively some practical population policies and programmes to curb the population growth. Many independent variables such as economic value of children in Nepalese agrarian economy, reduction of infant mortality and morbidity owing to the medical treatment facilities (though in limited extent), malaria eradication in the Tarai (shifting of the destination of hill

Mr. Laya Prasad Uprety is the Lecturer in Anthropology at the Central Department of Sociology/Anthropology, Tribhuvan University, Kirtipur, Kathmandu. 